\section{Polish government allows tentative steps towards academic autonomy}

\section{London}

"THERE can be no real development of science or our country without academic self-governance", Polish politbureau member Marian Orzechowski stated last month. His remark launched a series of concessions on academic autonomy that go a long way towards reversing the clamp-down of the 1985 Higher Education Act. In particular, although the proSolidarity Independent Students' Association (NZS) is still outlawed, for the first time since the imposition of martial law in December 1980 , some student organizations not affiliated to the official Association of Polish Students (ZSP) will be allowed to operate at the inter-university level.

Orzechowski was addressing the Main Council for Science and Higher Education, a 70-member elected body representing all Polish universities and higher colleges (excluding the Catholic University of Lublin which opted for observer status only). The Main Council was established during the Solidarity era (1980-81) and under the 1982 Higher Education Act the government was obliged to obtain its consent to major decisions on higher education policy. Under the 1985 Act, however, it was demoted to a consultative role only. Last month's meeting, while not restoring the Main Council's teeth, converted it into a more active forum for the

\section{Leicester makes bid for space eminence}

\section{London}

THE British 'space lobby' is continuing its efforts to strengthen Britain's position in space despite the government's lack of enthusiasm. Leicester University this week Flavour enhancer. launched a $£ 3$ million appeal for a new space centre. It will be self-financing, although initially funds will come from industrial and commercial investment. Due to be built and begin operation in 1990, the centre will host the country's first undergraduate degree course in space science and technology. It will be built on the same foundations as traditional physics courses but "will have a different flavour" says Professor Kenneth Pounds, head of physics. Courses will include space-craft systems design, space instrumentation, earth-observation science and orbital dynamics and space propulsion.

\section{exchange of ideas}

The Polish government is at present considering a number of changes in the law on higher education, which as Education Minister Henryk Bednarski told the Main Council, include the establishment of a Fundamental Research Council, described as a forum in which the voice of every scientist would carry the same weight, and new arrangements for the funding of research in the universities. The most pressing problem, however, is to restore an atmosphere of confidence within the universities.

Poland's endemic economic crisis has depressed both academic salaries and student stipends, and libraries and laboratories still depend on the generosity of Western colleagues for essential journals and equipment. Many talented young people are now reluctant to apply to university since by so doing they will merely commit themselves to five years of poverty in poor hostel conditions, with little or no hope of a decent salary at the end.

Moreover, the students have lost confidence in their official union, the ZSP. Less than 10 per cent of students belong to the official union, even though it tries to restrict certain material benefits to members only. During the past few years, students have called repeatedly for the legalization of the banned $\mathrm{NZS}$, and in some universities, NZS now operates openly, running bookstalls and holding meetings. Warsaw University's rector, Dr Grzegorz Bialkowski, has declared that he, for one, is prepared to liaise with NZS even now, on the grounds that it is the only genuine representative student opinion in his university.

At the end of September, a national conference of the ZSP admitted the need for "pluralism" of student organizations, not so much a concession as a pragmatic admission of its own weakness. A few days later, the first independent student organization since the Solidarity era was officially registered in Poznan, the Catholic-orientated Academic Union of Young Poland (ZAMP). A few days later, a similar organization, called Verbum, was founded in Gdansk. Furthermore, at the celebrations marking the opening of the academic year in Poznan last week, attended by party leader General Woicieck Jaruzelski, the rector of the Adam Mickiewwicz University of Poznan, Dr Jacek Fisiak, (since appointed minister of education) urged his students to take advantage of the new pluralism, which, he said, permits any student organization with "productive aims" providing it is not opposed to the constitution.

\section{Shroud a good forgery}

Zürich

AFTER weeks of rumour and speculation, the official carbon dating results for the Turin Shroud were released in Zürich last week. They show that the shroud, claimed by its proponents to be the burial shroud of Jesus Christ, is at most 728 years old, originating "with 95 per cent certainty" between AD 1260 and 1380 . Three laboratories at the Swiss Federal Polytechnic Institute, at the University of Arizona, and at Oxford University arrived at the dates in independent analyses.

The Catholic Church, which for years had refused to allow the shroud to be tested using destructive means such as radiocarbon dating, accepted the researchers' finding without dispute. The Archbishop of Turin, Anastasio Cardinal

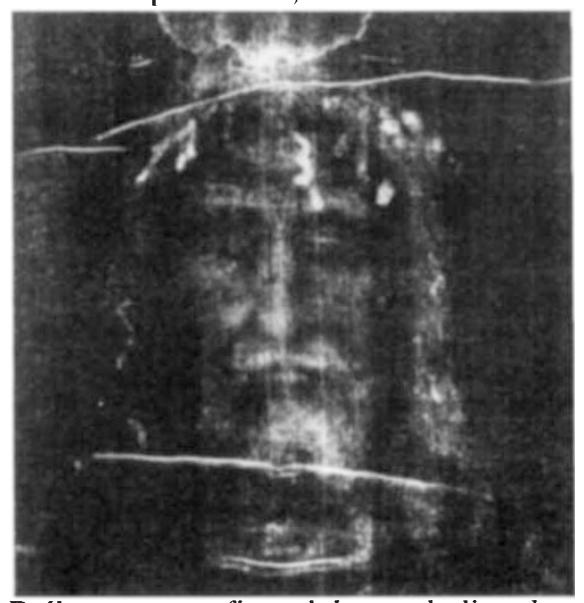

Ballestrero, confirmed the symbolic value of the shroud despite its lack of authenticity. The dating of the shroud was performed on just a few square centimetres of cloth taken from the edge of the linen shroud in April of this year, making use of techniques perfected during the past decade which rely on single atom counting using a particle accelerator.

Like traditional radiocarbon dating methods, the technique relies upon determining the ratio of carbon- 14 to carbon-12 isotopes in the sample. Living organisms accumulate the rarer carbon-14 isotopes during their lifetimes, but these unstable atoms decay over time (with a half-life of about 5,500 years) and cease to be replaced once an organism dies. The current method can determine the ratio to better than 1 per cent accuracy, corresponding to an uncertainty of less than 80 years either way.

Though the new results seem likely to end centuries-old speculation about the origins of the Shroud (a 1389 letter from the Bishop of Troyes to Pope Clement VII claimed it was a forgery), the source of the Christ-like image remains a mystery.

Steven Dickman 